\title{
PEMANFAATAN TRANSFORMASI NORMALIZED DIFFERENCE VEGETATION INDEX (NDVI) CITRA LANDSAT TM UNTUK ZONASI VEGETASI DI LERENG MERAPI BAGIAN SELATAN
}

\author{
Oleh: \\ Ardi Arnanto \\ Laboratorium SIG/SIP Sekolah Tinggi Pertanahan Nasional \\ JI. Tata Bumi No. 5 Yogyakarta 55293 \\ email: arnant_04@yahoo.com
}

\begin{abstract}
Abstrak
Penelitian ini berusaha untuk mengetahui pengaruh variasi jenis vegetasi, kerapatan tegakan, dan umur vegetasi terhadap informasi spektral vegetasi pada citra digital Landsat TM di Daerah Lereng Merapi Bagian Selatan. Tujuan yang dirumuskan dalam penelitian ini adalah untuk (1) mengkaji jenis, kerapatan tegakan, dan umur tegakan vegetasi berdasarkan nilai kecerahan piksel pada citra tranformasi (NDVI) data digital Landsat TM; (2) membuat zonasi vegetasi berdasarkan data digital Landsat TM. Metode yang digunakan dalam penelitian ini adalah transformasi indeks vegetasi dan kerja lapangan, sedangkan untuk pengambilan sampel digunakan metode stratified random sampling dan area sampling. Stratified random sampling didasarkan atas pengelompokkan nilai piksel pada citra transformasi indeks vegetasi, sedangkan area sampling digunakan karena nilai kecerahan pada data digital penginderaan jauh diujudkan dalam nilai piksel. Pemilihan sampeldengan mempertimbangkan jenis vegetasi dan kemudahan untuk dijangkau. Hasil penelitian yang diperoleh menunjukkan hubungan yang nyata antara nilai indeks vegetasi (NDVI) dengan variasi jenis vegetasi yang dapat digunakan sebagai dasar klasifikasi vegetasi. Sedangkan parameter kerapatan tegakan dan umur vegetasi mempunyai korelasi yang bersifat positif terhadap nilai indeks vegetasi (NDVI). Berdasarkan eratnya hubungan ini dapat dibuat citra atau peta distribusi kerapatan tegakan dan umur vegetasi. Secara umum tingkat ketelitian klasifikasi jenis vegetasi sebesar 93\%, sedangkan untuk kerapatan tegakan dan umur vegetasi mempunyai tingkat ketelitian sebesar $71 \%$ dan $76 \%$.
\end{abstract}

Kata kunci: Transformasi NDVI, Landsat TM, Vegetasi

\section{THE UTILIZATION OF TRANSFORMATION OF NORMALIZED DIFFERENCE VEGETATION INDEX (NDVI) LANDSAT-TM IMAGE FOR ZONING THE VEGETATION IN THE SOUTHERN OF MERAPI SLOPE}

\begin{abstract}
This study aims to know the effect of the variations of vegetation types, stand density, and the vegetation age to the vegetation spectral information of digital image Landsat $T M$ in the Southern part of Merapi Slope. The objectives formulated in this research are to (1) study the type, stand density, and vegetation age based on the pixels brightness values in the image transformation (NDVI) of Landsat TM digital data, (2) make the zoning of vegetation based on Landsat TM digital data. The method used in this study is the transformation of vegetation indexs and field work. Moreover, the techniques used to take the research samples are the stratified random sampling and sampling area. The stratified random sampling is based on the grouping of the pixel values in the image transformation vegetation index, while the sampling area is used because the brightness
\end{abstract}


value in remote sensing digital data is realized by the pixel values. The selection of the sampel considers the type of vegetation and the ease to reach. The findings show that the real relationship between vegetation index values (NDVI) and the variations of vegetation type can be used as a basis for classifiying the vegetation. Meanwhile, the parameters of stand density and the vegetation age have a positive correlation to the vegetation index values (NDVI). Based on this close relationship, image or map of the distribution of stand density and vegetation age is made. In general, the accuracy of vegetation type is $93 \%$, while stand density and the vegetation age have an accuracy level of $71 \%$ and $76 \%$ respectively.

\section{Keywords : Transformation of NDVI, Landsat TM, vegetation}

\section{Pendahuluan}

Vegetasi merupakan sumberdaya alam utama dalam kehidupan makhluk hidup, yaitu sebagai penyedia makanan dan tempat bernaung bagi hewan dan manusia. Dalam suatu ekosistem hanya vegetasi yang mampu menyediakan energi bagi makhluk hidup melalui proses fotosintesa dengan bantuan sinar matahari, dalam bentuk yang dapat dimanfaatkan oleh hewan maupun manusia berupa : daun, buah, biji, maupun ubi. Gangguan/kerusakan yang terjadi pada sekelompok vegetasi akan menyebabkan perubahan keseimbangan ekosistem tempat vegetasi itu berada.

Hutan merupakan salahsatu sumberdaya alam yang mempunyai peranan penting sebagai modal dasar pembangunan Indonesia. Hutan yang terdapat di Indonesia dapat berupa hutan alami maupun hutan buatan. Vegetasi yang terdapat di hutan beranekaragam yang dipengaruhi oleh jenis hutan itu, seperti hutan buatan : mempunyai vegetasi yang seragam, jarak tanamnya sama dan teratur, tersusun dari satu jenis vegetasi ataupun dalam satu petak hutan terdapat satu jenis pohon dengan umur dan ukuran yang sama dan masing-masing pohon tumbuh dengan pola yang teratur; hutan alami : mempunyai keragaman vegetasi yang bervariasi dalam hal jenis vegetasi, umur tegakan, kerapatan, kelembaban, maupun faktor fisik yang lain. Hutan di Indonesia termasuk hutan musim yang mempunyai ciri-ciri umum: vegetasi tidak begitu lebat seperti pada jenis hutan tropika basah walaupun bervariasi kenampakkannya, mempunyai kecenderungan terbuka dengan pohon-pohon penyusunnya lebih berjauhan dan tidak ada pergulatan diantara tumbuhan untuk mendapatkan cahaya, pada musim kering menggugurkan daunnya untuk mengurangi besarnya penguapan (Polunin, 1990 dalam Kriswantoro 1997). Untuk dapat mempertahankan laju pembangunan nasional dalam menentukan kebijaksanaan pengelolaan hutan harus memperhatikan aspek kelestarian dan produktivitas hutan. Ekosistem hutan didomonasi oleh vegetasi sebagai salah satu ciri khas kenampakan hutan.

Sampai saat ini masalah pengelolaan hutan di Indonesia merupakan suatu hal yang kompleks dan rumit. Karena dalam kegiatan pengelolaan hutan diperlukan suatu survei yang berulang-ulang, yang pada kenyataannya tidak dapat dilaksanakan secara rutin dan konvensional. Hal tersebut disebabkan survei lapangan dan survei udara membutuhkan biaya yang sangat besar dan waktu yang lama, khusunya untuk kawasan hutan dengan luasan yang besar serta keadaan medan yang sulit dan tidak mudah untuk dijangkau (Sutanto, 1994). 
Perkembangan teknologi penginderaan jauh dewasa ini ataupun dimasa mendatang memberikan kemungkinan untuk memperoleh data yang relatif baru, cepat, dan akurat. Peluncuran berbagai macam satelit oleh negara-negara maju semakin memacu perkembangan penginderaan jauh sebagai salah satu alat untuk memperoleh data inventarisasi sumberdaya alam yang handal. Adanya satelit-satelit Landsat, SPOT, ERS-1, NOAA, dan lain-lain yang mengorbit di bumi dengan berbagai jenis sensor, resolusi spektral, dan resolusi spasial sangat menguntungkan para pemakai data satelit sesuai dengan kebutuhannya.

Banyaknya saluran pada Landsat Thematic Mapper yang beroperasi pada saluran yang peka terhadap respon spektral vegetasi sangat menguntungkan dalam penelitian atau studi tentang vegetasi. Dengan bantuan transformasi matematis yang berupa indeks vegetasi maka nilai spektral vegetasi dapat ditonjolkan, sedangkan nilai spektral diluar vegetasi dapat dihilangkan atau dieleminiasi, sehingga memungkinkan untuk dilakukan studi tentang kerapatan vegetasi, Leaf Area Index (LAI), biomassa, umur tegakan, konsentrasi klorofil, dan juga kandungan nitrogen (Danoedoro, 1993).

Adapu tujuan dari penelitian ini antara lain: (1) Mengkaji jenis, kerapatan tegakan, dan umur tegakan vegetasi berdasarkan nilai kecerahan piksel pada citra tranformasi data digital Landsat TM, (2) Membuat zonasi vegetasi berdasarkan data digital Landsat TM.

\section{Metode Penelitian}

Daerah penelitian termasuk dalam wilayah administrasi Kabupaten Sleman, Propinsi Daerah Istimewa Yogyakarta, Kabupaten Magelang, dan Kabupaten Klaten, Propinsi Jawa Tengah.

Secara administratif daerah penelitian tesebut berbatasan dengan :

Sebelah utara adalah Kecamatan Selo, Kabupaten Boyolali

Sebelah timur adalah Kecamatan Kemusuk, Kabupaten Boyolali.

Sebelah selatan adalah Kecamatan Turi, Kecamatan Pakem, dan Kecamatan Cangkringan, Kabupaten Sleman.

Sebelah barat adalah Kecamatan Srumbung, Kabupaten Magelang. Secara astronomis daerah penelitian terletak pada $7^{\circ} 33^{\prime} \mathrm{LS}$ hingga $7^{\circ} 40^{\prime} \mathrm{LS}$ dan $110^{\circ} 23^{\prime}$ BT hingga $110^{\circ} 29^{\prime}$ BT.

Metode yang digunakan dalam pelaksanaan penelitian ini adalah gabungan antara analisis digital dengan pendekatan pola spektral indeks vegetasi data Landsat TM secara multispektral dan kerja lapangan untuk mengetahui kondisi nyata di lapangan dan menguji ketelitian hasil interpretasi citra indeks vegetasi.

Data digital Landsat TM dalam penelitian ini diproses dengan menerapkan transformasi indeks vegetasi NDVI (Normalized Difference Vegetation Index). Pekerjaan uji lapangan yang dilakukan meliputi : (a) menilai dan mencocokkan nilai spektral jenis dan kerapatan vegetasi dengan hasil analisis digital citra indeks vegetasi di laboratorium dengan kenyataan di lapangan, (b) pengukuran presentase kerapatan tegakan vegetasi.

1. Analisis Data Digital

a. Perbaikan Citra

Pada dasarnya, semua citra digital yang telah terekam oleh sensor, dan disimpan dalam format yang dapat dibaca oleh program pengolah citra, akan dapat ditampilkan 
pada layar monitor. Melalui layar monitor ini, kulaitas citra akan dapat terlihat dengan jelas, baik dan buruknya. Kualitas citra dapat ditentukan secara kuantitatif, tetapi dapat pula kualitatif. Restorasi citra diperlukan, apabila kualitas citra yang akan digunakan tidak mencukupi dalam mendukung studi tertentu. Namun sebenarnya semua citra yang diperoleh melalui perekaman sensor tak lepas dari kesalahan, yang diakibatkan oleh mekanisme perekaman sensornya, gerakan dan ujud geometri bumi, serta kondisi atmosfer pada saat perekaman.

Transformasi geometri yang paling mendasar adalah penempatan kembali posisi piksel sedemikian rupa, sehingga pada citra digital yang tertransformasi dapat dilihat gambaran obyek di permukaan bumi yang terekamsensor. Pengubahan bentuk kerangka liputan dari bujur sangkar menjadi jajaran genjang merupakan hasil dari transformasi ini. Tahap ini diterapkan pada citra digital mentah (langsung hasil perekaman satelit), danmerupakan koreksi kesalahan geometrik sistematik.

Koreksi radiometrik diperlukan atas dua alasan, yaitu untuk memperbaiki kualitas visual citra dan sekaligus memperbaiki nilai-nilai piksel yang tidak sesuai dengan nilai pantulan atau pancaran spektral obyek yang sebenarnya. Koreksi radiometri citra yang ditujukan untuk memperbaiki kualitas visual citra berupa pengisian kembali baris yang kosong karena drop-out baris maupun masalah kesalahan awal pelarikan (scanning start). Baris atau bagian baris yang bernilai tidak sesuai dengan yang seharusnya dikoreksi dengan mengambil nilai piksel satu baris di atas dan di bawahnya, kemudian dirataratakan (Guindon, 1984, dalam Danoedoro, 1996)

b. Ekstraksi Informasi

Penajaman kontras diterapkan untuk memperoleh kesan kontras citra yang lebih tinggi. Hal ini dapat dilakukan dengan mentransformasi seluruh nilai kecerahan. Hasilnya berupa citra dengan nilai maksimum awal, dan nilai minimum baru yang (pada umumnya) lebih rendah dari nilai minimum awal. Secara visual, hasil ini berupa citra baru yang variasi hitam-putihnya lebih menonjol, sehingga tampak lebih tajam dan memudahkan proses interpretasi. Algoritma penajaman kontras ini dapat dikelompokkan menjadi dua : perentangan kontras (contrast stretching) dan ekualisasi histogram (histogram equalization).

Indeks vegetasi merupakan suatu algoritma yang diterapkan terhadap citra (biasanya multisaluran), untuk menonjolkan aspek kerapatan vegetasi ataupun aspek yang berkaitan dengan kerapatan, misalnya biomassa, Leaf Area Index (LAI), konsentrasi klorofil, dan ebagainya. Secara praktis, indeks vegetasi ini merupakan suatu transformasi matematis yang melibatkan beberapa saluran sekaligus, dan menghasilkan citra baru yang lebih representatif dalam menyajikan fenomena vegetasi.

Normalized Difference Vegetation Index (NDVI) merupakan kombinasi antara tehnik penisbahan dengan tehnik pengurangan citra. Transformasi NDVI ini merupakan salah satu produk standar NOAA (National Oceanic and Atmospheric Administration), satelit cuaca yang berorbit polar namun memberi perhatian khusus pada fenomena global vegetasi. Berbagai penelitian mengenai perubahan liputan vegetasi di benua Afrika banyak menggunakan transformasi ini (Tucker, 1986, dalam Danoedoro, 1996). 
Formulasinya adalah sebagai berikut :

$$
\text { NDVI }=\frac{(\text { saluran IR dekat }- \text { saluran merah })}{(\text { salkran IR dekat }+ \text { sahwan merah })}
$$

2.

Analisis Statistik

Analisis statistik dilakukan untuk mengetahui kekuatan dan bentuk pengaruh antara variabel yang diuji. Analisis yang digunakan adalah analisis korelasi dan analisis regresi, dimana analisis korelasi dimaksudkan untuk mengetahui derajat hubungan antara variabel $\mathrm{x}$ yang berisi data transformasi indeks vegatasi dengan variabel y yang berisi hasil pengukuran lapangan, sedangkan analisis regresi dimaksudkan untuk mengetahui besarnya pengruh yang diakibatkan adanya perubahan pada setiap satuan variabel $x$. Ukuran kekuatan pengaruh ditentukan dengan menggunakan besarnya koefisien korelasi (r) dan koefisien determinasi $\left(r^{2}\right)$.

Koefisien korelasi dicari dengan rumus :

$$
r=\frac{\left(n \sum x i y i\right)-\left(\sum x i\right)\left(\sum y i\right)}{\sqrt{\left[\left(\left(n \sum x i^{2}\right)-\left(\sum x i^{2}\right)\right)\left(\left(n \sum y i^{2}\right)-\left(\sum y i^{2}\right)\right)\right]}}
$$

Formula regresi :

$$
y=a x^{b}
$$

Koefisien a dan $\mathrm{b}$ ditentukan dengan cara :

$$
\begin{aligned}
& \log a=\frac{\left(\sum \log y i\right)}{n}-b \frac{2 \log z i}{n} \\
& b=\frac{n\left(\sum \log x i \log y i\right)-\left(\sum \log x i\right)\left(\sum \log y i\right)}{n\left(\sum \log ^{2} x i\right)-\left(\sum \log y i\right)}
\end{aligned}
$$

\section{Dengan :}

$\mathrm{n}=$ besarnya populasi sampel

$\mathrm{x}=$ variabel bebas, yaitu jenis dan kerapatan vegetasi (data lapangan)

$y=$ variabel terikat, yaitu nilai kecerahan piksel pada transformasi multispektral.

\section{Uji Ketelitian Interpretasi}

Uji ketelitian interpretasi dari data Landsat dapat dilakukan dengan empat cara (Short, 1982 dalam Jamaludin 2002) yaitu : cek lapangan pada titik-titik yang dipilih, mencocokan antara data landsat dan peta-peta referensi, analisis statistik, dan

\begin{tabular}{|c|c|c|c|c|c|}
\hline \multirow{2}{*}{$\begin{array}{c}\text { Kelas } \\
\text { di Lapangan }\end{array}$} & \multicolumn{4}{|c|}{ Kelas Data Landsat } & \multirow[t]{2}{*}{ Total } \\
\hline & $\bar{A}$ & $B$ & C & $\bar{D}$ & \\
\hline A & 25 & 5 & 10 & 3 & 43 \\
\hline$B$ & 2 & 50 & 6 & 5 & 63 \\
\hline$C$ & 3 & 4 & 60 & 5 & 72 \\
\hline$D$ & 2 & 2 & 2 & 100 & 106 \\
\hline Total & 32 & 61 & 78 & 113 & 284 \\
\hline
\end{tabular}
perhitungan confusion matrix.

Pada penelitian ini uji ketelitian interpretasi menggunakan metode perhitungan confusion matrix. Contoh perhitungan uji ketelitian interpretasi (Short, 1982).

Tabel 1. Matrik Uji Ketelitian Interpretasi

Sumber : Short, 1982 dengan modifikasi 
Pemanfaatan Transformasi Normalized Difference Vegetation Index (Ndvi) Citra Landsat TM untuk Zonasi Vegetasi di Lereng Merapi Bagian Selatan

Untuk menghitung seberapa besar tingkat ketelitian dari interpretasi digunakan rumus:

Tingkat ketelitian interpretasi $=\frac{J \text { ml piksel baw }}{J \text { ml keselumhan piksel }} \times 100 \%$
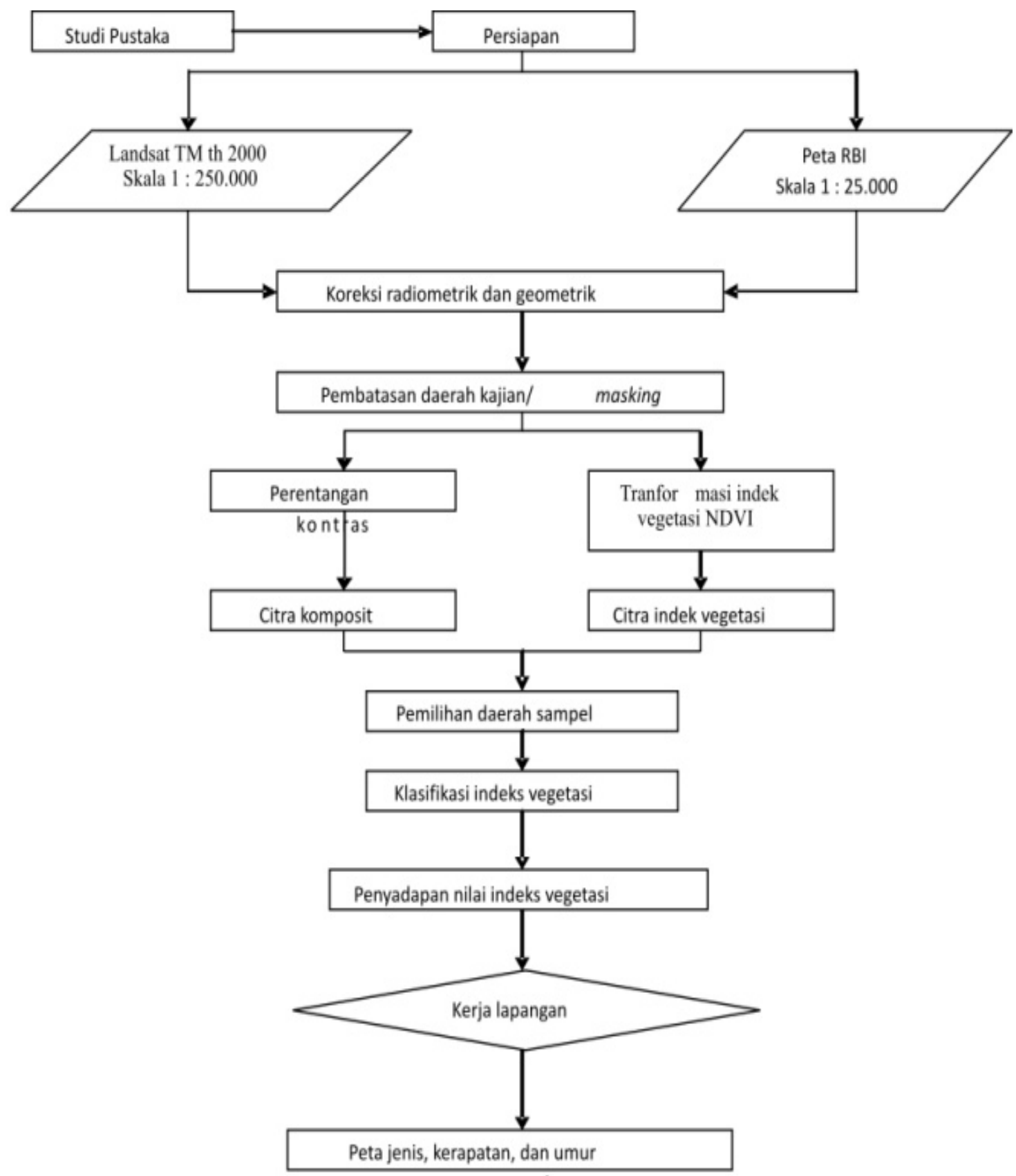

Gambar 1. Diagram Alir Penelitian

\section{Hasil dan Pembahasan}

1. Hasil Pengolahan dengan Transformasi Indeks Vegetasi (NDVI)

Indeks vegetasi merupakan suatu algoritma yang diterapkan terhadap citra digital, dimaksudkan untuk menonjolkan aspek-aspek vegetasi. Seperti aspek kerapatan, jenis, umur, ataupun aspek-aspek lain yang berkaitan dengan vegetasi. 
Dalam penelitian ini mengkaji seberapa besar kemampuan citra hasil transformasi indeks vegetasi dalam membedakan variabel jenis, kerapatan tegakan, dan umur vegetasi. Tehnik penisbahan yang digunakan adalah Normalized Difference Vegetation Index (NDVI).

Citra hasil transformasi digunakan sebagai acuan dalam penetuan titik-titik sampel. Terlihat jelas pengelompokan nilai indeks vegetasi dan masing-masing pengelompokan nilai tersebut diambil sampel untuk identifikasi parameternya, yaitu jenis, kerapatan tegakan, maupun umur vegetasi. Hasil pengamatan titik sampel dilapangan kemudian dinyatakan secara kuantitatif dan dikaitkan dengan nilai-nilai indeks vegetasi pada posisi piksel yang sama.

Nilai indeks vegetasi yang paling tinggi dalam citra diwakili oleh warna merah dan makin rendah berwarna hijau hingga warna biru yang mewakili nilai piksel terendah. Dari parameter jenis vegetasi didapatkan hasil bahwa pinus mempunyai nilai indeks vegetasi rata-rata paling tinggi yaitu 0,592082, kemudian akasia mempunyai nilai indeks vegetasi rata-rata 0,396662, bambu mempunyai nilai indeks vegetasi rata-rata 0,476632, puspa mempunyai nilai indeks vegetasi rata-rata 0,543649 , dan nilai terendah terdapat pada lahan yang tak bervegetasi dengan rata-rata nilai indeks vegetasi 0,034276. Hasil pengamatan pengaruh jenis vegetasi terhadap nilai indeks vegetasi dapat dilihat pada tabel 2.

Tabel 2. Pengaruh jenis vegetasi terhadap nilai indeks vegetasi

\begin{tabular}{|l|cc|c|r|}
\hline \multirow{2}{*}{ Jenis Vegetasi } & \multicolumn{4}{|c|}{ Nilai Indeks Vegetasi } \\
& Min & Max & Mean & St. Deviasi \\
\hline Pinus & 0.500000 & 0.686957 & 0.592082 & 0.037499 \\
\hline Akasia & 0.255814 & 0.457143 & 0.396662 & 0.060265 \\
\hline Bambu & 0.463415 & 0.487805 & 0.476632 & 0.006984 \\
\hline Puspa & 0.500000 & 0.620000 & 0.543649 & 0.034158 \\
\hline Tak berveqetasi & -0.200000 & 0.100000 & 0.034276 & 0.053043 \\
\hline
\end{tabular}

Sumber : Data Digital Landsat TM tahun 2000.

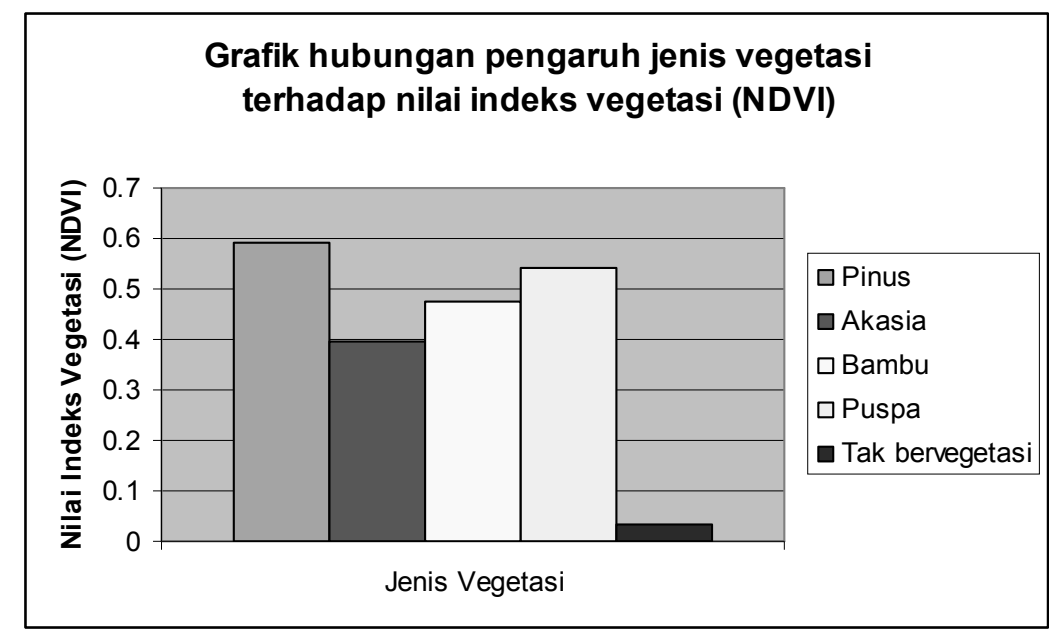

Gambar 2. Grafik hubungan pengaruh jenis vegetasi terhadap nilai indeks vegetasi (NDVI). 
Ukuran parameter yang lain yaitu kerapatan tegakan memperlihatkan pola bahwa semakin tinggi kerapatan tegakan vegetasinya semakin tinggi pula nilai indeks vegetasinya. Berdasarkan pengamatan di lapangan, vegetasi dengan kerapatan 229 pohon/ha mempunyai nilai indeks vegetasi rata-rata 0,602548 dan semakin menurun bersamaan dengan berkurangnya kerapatan hingga nilai indeks vegetasi rata-ratanya 0,34446 untuk kerapatan 4 pohon/ha. Sedangkan untuk lahan tak bervegetasi nilai indeks vegetasinya dapat mencapai - 0,233993 yang terdapat di daerah puncak. Hasil pengamatan pengaruh kerapatan tegakan vegetasi terhadap nilai indeks vegetasi dapat dilihat pada tabel 3 .

Tabel 3. Pengaruh kerapatan tegakan terhadap nilai indeks vegetasi

\begin{tabular}{|l|c|c|c|c|}
\hline \multirow{2}{*}{ Kerapatan Tegakan } & \multicolumn{4}{|c|}{ Nilai Indeks Vegetasi } \\
\cline { 2 - 5 } & Min & Max & Mean & St. Deviasi \\
\hline $4 \mathrm{phn} / \mathrm{hs}$ & 0.244444 & 0.428571 & 0.347448 & 0.041493 \\
\hline $7 \mathrm{phn} / \mathrm{hs}$ & 0.200000 & 0.487179 & 0.385135 & 0.046051 \\
\hline $37 \mathrm{phn} / \mathrm{hs}$ & 0.397590 & 0.576471 & 0.508508 & 0.029940 \\
\hline $120 \mathrm{phn} / \mathrm{hs}$ & 0.269231 & 0.469880 & 0.403262 & 0.035234 \\
\hline $160 \mathrm{phn} / \mathrm{hs}$ & 0.542169 & 0.661017 & 0.583739 & 0.021669 \\
\hline $229 \mathrm{phn} / \mathrm{hs}$ & 0.480519 & 0.686957 & 0.602548 & 0.042854 \\
\hline
\end{tabular}

Sumber : Data Digital Landsat TM tahun 2000.

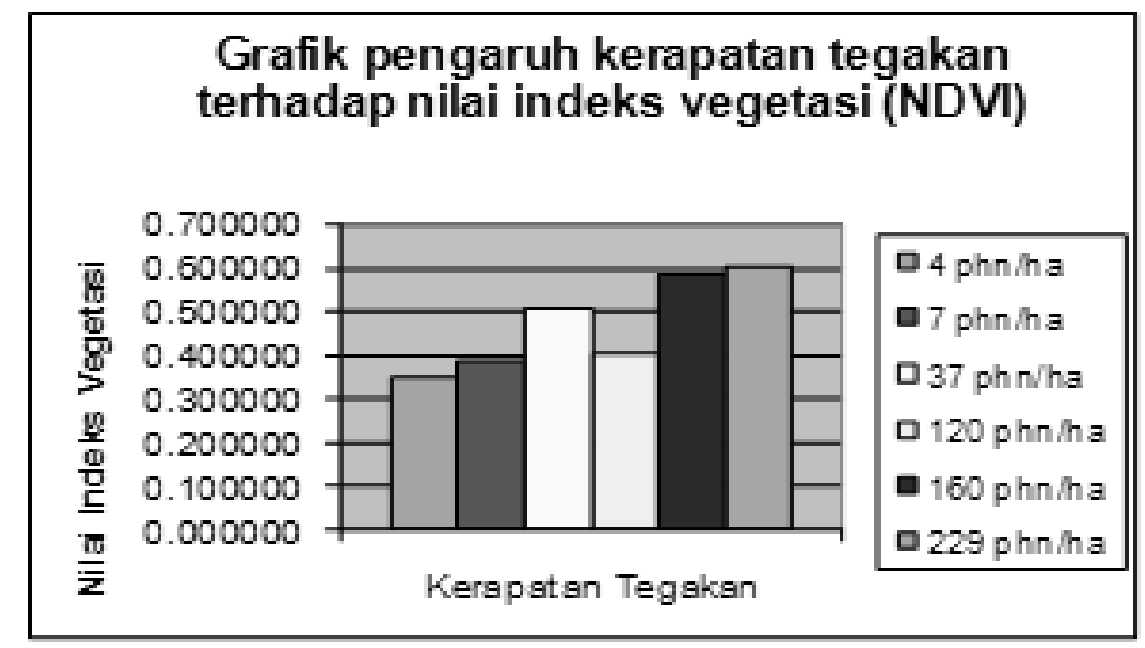

Gambar 3. Grafik hubungan kerapatan tegakan vegetasi terhadap nilai indeks vegetasi (NDVI)

Parameter umur vegetasi juga memperlihatkan pola yang sama, semakin tua umur vegetasi semakin tinggi pula nilai indeks vegetasinya. Pada vegetasi umur 70 th mempunyai nilai indeks vegetasi rata-rata 0,608477 dan semakin turun hingga umur 10 tahun mempunyai nilai indeks vegetasi rata-rata 0,407386. Hasil pengamatan pengaruh umur vegetasi terhadap nilai indeks vegetasi dapat dilihat pada tabel 4 . 
Tabel 4. Pengaruh umur tegakan vegetasi terhadap nilai indeks vegetasi

\begin{tabular}{|l|c|c|c|r|}
\hline \multirow{2}{*}{ Umur Tegakan } & \multicolumn{4}{|c|}{ Nilai Indeks Vegetasi } \\
\cline { 2 - 5 } & Min & Max & Mean & St. Deviasi \\
\hline 10 th & 0.333333 & 0.459459 & 0.407386 & 0.027248 \\
\hline 20 th & 0.381818 & 0.500000 & 0.441878 & 0.031011 \\
\hline 42 th & 0.448276 & 0.579832 & 0.513008 & 0.033725 \\
\hline 70 th & 0.548387 & 0.638889 & 0.608477 & 0.021359 \\
\hline
\end{tabular}

Sumber : Data Digital Landsat TM tahun 2000.

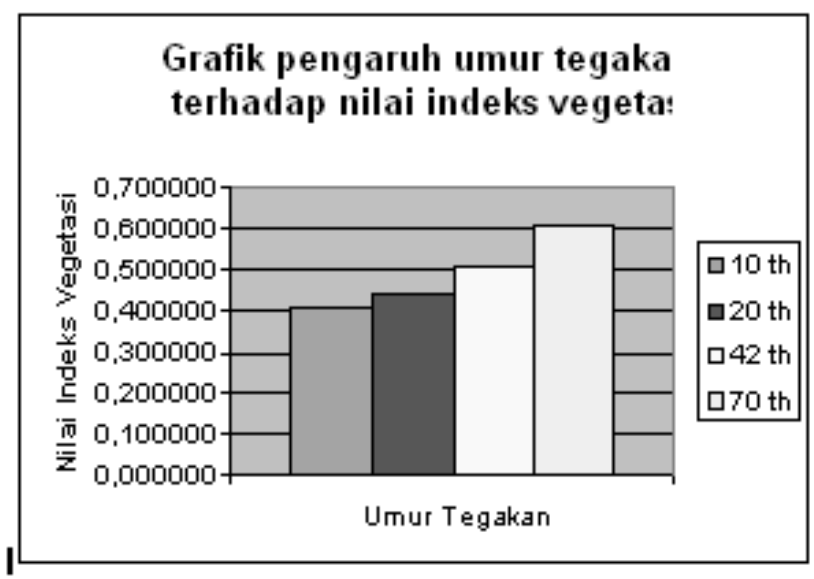

Gambar 4. Grafik hubungan pengaruh umur vegetasi dengan nilai indeks vegetasi (NDVI)

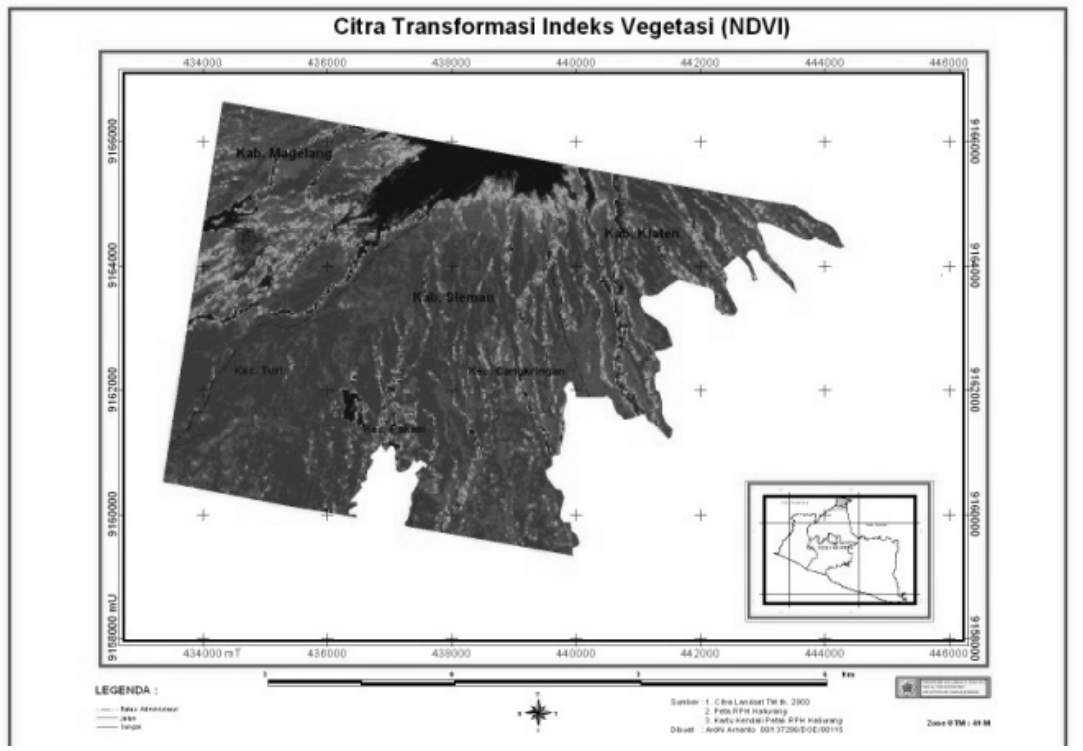

Gambar 5. Peta Citra Transformasi NDVI

\section{Hasil Pengolahan Data Lapangan}

Data lapangan yang didapatkan berupa data jenis vegetasi, kerapatan tegakan, dan umur vegetasi dicari seberapa besar kekuatan dan pengaruhnya terhadap nilai piksel dalam citra transformasi indeks vegetasi. Untuk mengukur pengaruh dari variabel data terhadap nilai piksel digunakan metode analisis korelasi dan regresi. Besarnya kekuatan 
Pemanfaatan Transformasi Normalized Difference Vegetation Index (Ndvi) Citra Landsat TM untuk Zonasi Vegetasi di Lereng Merapi Bagian Selatan

pengaruh variabel diukur dengan nilai koefisien korelasi yang nilainya berkisar antara 1 sampai 0 dan 0 sampai -1 . Semakin mendekati nilai 0 maka semakin kecil pengaruh variabelnya. Nilai koefisien korelasi (+) menunjukkan bahwa hubungan antar variabel searah, kenaikan nilai variabel pengaruh diikuti kenaikan pula pada nilai variabel yang dipengaruhi. Sedangkan nilai (-) menunjukkan hubungan berkebalikan, yaitu kenaikan nilai variabel pengaruh akan diikuti penurunan nilai variabel terpengaruh.

Fungsi regresi yang dinyatakan dalam $\mathrm{Y}=\mathrm{Xb}$ menunjukkan hubungan antara 2 variabel. Dari hasil fungsi regresi yang didapatkan digunakan sebagai dasar untuk estimasi masing-masing variabel, dalam hal ini data kerapatan dan umur vegetasi. Analisis statistik ini digunakan untuk data-data kuantitatif dan bukan data kualitatif sehingga data yang bisa digunakan dalam analisis ini hanya data kerapatan tegakan dan umur vegetasi.

Tabel 5. Perhitungan statistik data umur vegetasi

\begin{tabular}{|r|c|c|c|c|c|c|c|c|c|c|}
\hline xi & yi & xiyi & xi2 & yi2 & $\mathbf{n}$ & $\log \mathbf{x i}$ & log yi & logxi logyi & log2 xi & log2 yi \\
\hline 10 & 0,407386 & 4,07386 & 100 & 0,165963353 & 4 & 1,000000 & $-0,389994$ & $-0,389994$ & 1,000000 & 0,152095 \\
\hline 20 & 0,441878 & 8,83756 & 400 & 0,195256167 & & 1,301030 & $-0,354698$ & $-0,461472$ & 1,692679 & 0,125810 \\
\hline 42 & 0,513008 & 21,546336 & 1764 & 0,263177208 & & 1,623249 & $-0,289876$ & $-0,470541$ & 2,634938 & 0,084028 \\
\hline 70 & 0,608477 & 42,59339 & 4900 & 0,37024426 & & 1,845098 & $-0,215756$ & $-0,398091$ & 3,404387 & 0,046551 \\
\hline $\mathbf{1 4 2}$ & $\mathbf{1 , 9 7 0 7 4 9}$ & $\mathbf{7 7 , 0 5 1 1 4 6}$ & $\mathbf{7 1 6 4}$ & $\mathbf{0 , 9 9 4 6 4 0 9 8 7}$ & & $\mathbf{5 , 7 6 9 3 7 7}$ & $\mathbf{- 1 , 2 5 0 3 2 3}$ & $\mathbf{- 1 , 7 2 0 0 9 8}$ & $\mathbf{8 , 7 3 2 0 0 4}$ & $\mathbf{0 , 4 0 8 4 8 4}$ \\
\hline
\end{tabular}

Sumber : Hasil Analisis tahun 2004

$$
\begin{aligned}
& r=\frac{4 \cdot 77,05115-142 \cdot 1,970749}{\sqrt{4 \cdot 7164-142^{2}} \sqrt{4 \cdot 0,994641-1,970749^{2}}}=0,999932 \\
& b=\frac{4 .(-1,720098)-5,769377 \cdot(-1,250323)}{4 \cdot 8,372004-0,408484}=0,009666 \\
& \log a=\frac{-1,250323}{4}-0,009666 \frac{5,769377}{4}=-0,326522 \\
& \quad a=0,471496 \\
& Y=0,471496 X^{0,009666}
\end{aligned}
$$

\begin{tabular}{|c|c|c|c|c|c|c|c|c|c|c|}
\hline$x i$ & yi & xiyi & $\mathrm{xi2}$ & yi2 & $n$ & $\log x i$ & $\log y i$ & logxi logyi & $\log 2 x i$ & $\log 2 \mathrm{yi}$ \\
\hline 4 & 0,347446 & 1,389784 & 16 & 0,120719 & 6 & 0,602060 & $-0,459113$ & $-0,276413$ & 0,362476233 & 0,210784456 \\
\hline 7 & 0,385135 & 2,695945 & 49 & 0,148329 & & 0,845098 & $-0,414387$ & $-0,350198$ & 0,714190697 & 0,171716596 \\
\hline 37 & 0,508508 & 18,814796 & 1369 & 0,258580 & & 1,568202 & $-0,293702$ & $-0,460584$ & 2,459256647 & 0,086260988 \\
\hline 120 & 0,403262 & 48,391440 & 14400 & 0,162620 & & 2,079181 & $-0,394413$ & $-0,820055$ & 4,322994654 & 0,155561378 \\
\hline 160 & 0,583739 & 93,398240 & 25600 & 0,340751 & & 2,204120 & $-0,233781$ & $-0,515282$ & 4,858144898 & 0,054653692 \\
\hline 229 & 0,602548 & 137,983492 & 52441 & 0,363064 & & 2,359835 & $-0,220008$ & $-0,519184$ & 5,568823504 & 0,048403674 \\
\hline 557 & 2,830638 & 302,673697 & 93875 & 1,394064 & & 9,658496 & $-2,015404$ & $-2,941716$ & 18,28588663 & 0,727380785 \\
\hline
\end{tabular}

Tabel 6. Perhitungan statistik data kerapatan tegakan

Sumber : Hasil Analisis tahun 2004 


$$
\begin{aligned}
& r=\frac{6.302,673697-557.2,830638}{\sqrt{6.93875-557^{2} \sqrt{6.1,394064-2,830638^{2}}}=0,802285} \\
& b=\frac{6 .(-2,941716)-9,658496 .(-2,015404)}{6.18,28589-0,727381}=0,016685 \\
& \log a=\frac{-2,941716}{6}-0,016658 \frac{9,658496}{6}=-0,517110 \\
& \quad a=0,304018 \\
& Y=0,304018 X^{0,016685}
\end{aligned}
$$

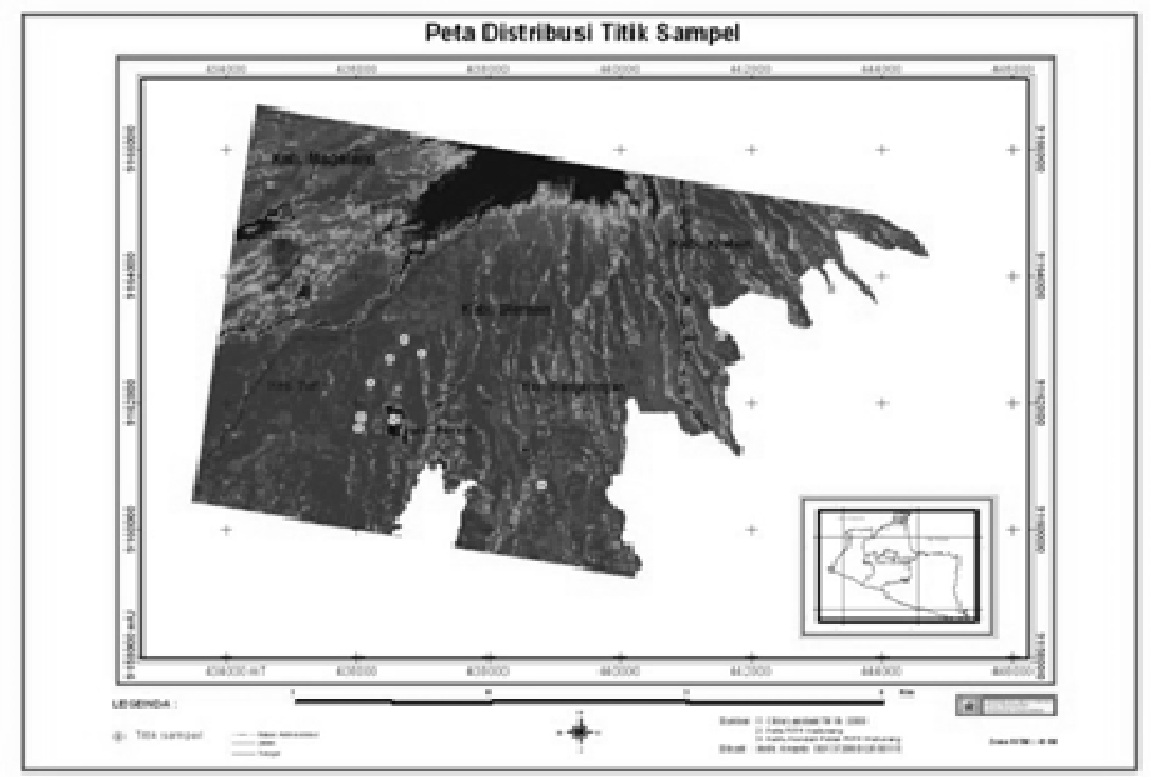

Gambar 6. Peta Sebaran Titik Sampel

\section{Tinjauan Hasil Secara Umum}

Masing-masing parameter vegetasi yang diambil dalam penelitian ini menunjukkan hubungan yang kuat, baik itu parameter kualitatif seperti jenis vegetasi ataupun parameter kuantitatif seperti umur vegetasi dan kerapatan tegakan. Setiap perubahan pada masing-masing parameter diikuti pula perubahan nilai piksel pada citra transformasi indeks vegetasi dengan pola yang relatif tetap. Hal ini dijadikan dasar dalam klasifikasi citra.

Hubungan nilai piksel citra transformasi indeks vegetasi dengan jenis vegetasi hanya mampu diukur secara relatif berdasarkan pengelompokkan nilai piksel. Masingmasing kelompok nilai piksel dari nilai piksel tertinggi hingga nilai piksel terendah diambil sampel di lapangan untuk diidentifikasi jenis vegetasinya. Pinus mempunyai nilai piksel tertinggi dengan rata-rata nilai piksel 0,592082, akasia mempunyai nilai piksel rata-rata 0,396662, bambu mempunyai nilai piksel rata-rata 0,487805, sedangkan puspa mempunyai nilai piksel rata-rata 0,543649. Nilai piksel terendah terdapat pada lahan yang tak bervegetasi dengan rata-rata nilai 0,034276. Dari seluruh data yang ada dapat diasumsikan bahwa masing-masing kelompok nilai piksel tersebut dapat diidentifikasi jenis vegetasinya berdasarkan nilai piksel yang ada pada citra transformasi indeks vegetasi. 
Kerapatan tegakan menunjukkan hubungan yang sangat kuat dengan nilai piksel pada citra transformasi indeks vegetasi. Hal ini ditunjukkan dengan nilai koefisien korelasi (r) yang mencapai 0,802285 . Nilai positif $(+)$ pada nilai koefisien korelasi berarti bahwa setiap kenaikan nilai kerapatan tegakan diikuti dengan kenaikan nilai indeks vegetasinya. Dari analisis regresi didapatkan rumus $Y=0,304018$ X0,016658.

Umur vegetasi juga menunjukkan hubungan yang sangat kuat dengan nilai piksel pada citra transformasi indeks vegetasi. Nilai korelasi antara kedua variabel tersebut adalah 0,999932 yang juga bernilai positif (+). Hasil analisis regresi didapatkan rumus $Y=$ 0,471496 X0,009666.

\section{Faktor yang Mempengaruhi Data Penelitian}

Hal penting yang perlu diperhatikan dalam penggunaan metode semacam ini ialah perlunya kalibrasi ataupun pertimbangan mengenai kemungkinan perbedaan informasi spektral obyek antara tanggal perekaman dengan tanggal pengambilan sampel mengingat obyek kajian (vegetasi) yang relatif dinamis. Pada musim kemarau kebanyakan vegetasi akan menggugurkan daunnya untuk mengurangi penguapan air. Walaupun untuk topografi daerah kajian yang berupa lereng gunung api dengan suhu yang relatif lebih dingin bila dibandingkan dengan dataran rendah, kegiatan pengguguran daun tidak terlalu terjadi secara signifikan namun faktor ini tetap menjadi bahan pertimbangan dalam penelitian.

Dalam header data digital Landsat TM tercatat bahwa data tersebut terekam pada bulan September tahun 2000. Idealnya kerja lapangan dilakukan pada bulan yang sama untuk meminimalkan perbedaan yang terjadi, namun pada penelitian ini kerja lapangan baru bisa terlaksana pada bulan Desember. Pada bulan September yang merupakan bulan-bulan awal memasuki musim hujan, dengan rentang perbedaan waktu 2 bulan dengan bulan perekaman data kemungkinan perubahan yang terjadi adalah perubahan dari tutupan kanopi vegetasi. Pada bulan Desember kemungkinan besar tutupan kanopi vegetasi relatif lebih tebal apabila dibandingkan dengan tutupan kanopi pada bulan September. Perbedaan tebal tutupan kanopi ini akan berpengaruh pada nilai piksel citra digital.

Variabilitas vegetasi juga sangat mempengaruhi nilai piksel pada citra digital. Hal ini yang dijadikan obyek dalam penelitian ini. Perbedaan struktur daun dalam tiap individu jenis vegetasi banyak berpengaruh terhadap nilai indeks vegatasi pada citra. Hal ini telah banyak diungkapkan dalam berbagai penelitian. Pengaruh utama terhadap karakteristik pemantulan daun diantara berbagai spesies tumbuhan ialah perbedaan ketebalan daun yang berakibat pada perbedaan kandungan pigmen dan perbedaan struktur fisiologis daun. Analisis citra digital dengan metode tranformasi indeks vegetasi akan lebih efektif untuk obyek kajian yang mempunyai wilayah persebaran yang luas dan homogen. Dan hal ini sulit ditemui di daerah hutan Indonesia yang pada umunya heterogen, demikian pula yang terjadi pada daerah penelitian. Hampir semua blok hutan dengan jenis tanaman tertentu tidak mempunyai persebaran yang luas, persebaranya sporadis dalam blok-blok yang sempit. Daerah penelitian secara umum terdiri atas tiga macam hutan, yaitu hutan alam, hutan wisata, dan hutan buatan. Hutan alam ialah hutan yang vegetasinya tumbuh secara alami tanpa campur tangan manusia, dan hutan jenis ini banyak dijumpai di lereng 
atas. Jenis tanaman di daerah ini sangat heterogen dan hal ini sangat menyulitkan dalam ekstraksi informasi dari citra, dan kemungkinan kebenaran hasil klasifikasi dengan analisis citra digital sangatlah kecil. Untuk daerah ini agak diabaikan, pengambilan sampel di lapangan sebagian besar dilakukan di bagian hutan buatan yang mempunyai jenis vegetasi homogen untuk dasar klasifikasi pada citra transformasi indeks vegetasi. Kesulitan timbul karena blok-blok pada hutan buatan tidak mempunyai persebaran yang luas sehingga sangat sulit menentukan letak kumpulan piksel yang tepat pada citra.

Variabel lain yang menjadi obyek dalam penelitian ini adalah umur vegetasi dan kerapatan tegakan. Jika dianalisis secara individu vegetasi, perbedaan umur vegetasi terhadap nilai indeks vegetasi diakibatkan perubahan struktur daun. Namun dalam penelitian ini dasar analisis tidak diarahkan pada individu vegetasi tetapi komunitas vegetasi. Dengan asumsi bahwa semakin bertambah umur vegetasi maka semakin tebal tutupan kanopinya sehingga semakin bertambah umur vegetasi semakin tinggi pula nilai indeks vegetasinya. Dari hasil analisis juga menunjukkan hubungan yang searah, yaitu kenaikan umur vegetasi diikuti dengan kenaikan nilai indeks vegetasinya. Demikian pula dengan variabel kerapatan tegakan, diasumsikan semakin rapat tegakan vegetasinya maka semakin besar pula kerapatan kanopinya, dan akan berpengaruh terhadap nilai indeks vegetasi. Dalam banyak penelitian didapatkan hasil, kenaikan kerapatan kanopi akan diikuti kenaikan nilai indeks vegetasinya. Dalam penelitian ini dianologikan bahwa kenaikan kerapatan tegakan akan diikuti kenaikan indeks vegetasinya pula. Hasil analisis menunjukkan hubungan yang kuat antara kerapatan tegakan dengan nilai indeks vegetasi, yaitu $r=0,802285$.

Banyak penelitian menyebutkan analisis indeks vegetasi efektif untuk vegetasi yang homogen. Seharusnya analisis kerapatan tegakan dan umur vegetasi dilakukan secara bertahap yaitu dengan membagi terlebih dahulu daerah kajian menjadi blok-blok berdasarkan jenis vegetasinya, baru setelah itu masing-masing blok vegetasi yang seragam dianalisis. Namun hal ini tidak bisa dilakukan pada daerah penelitian karena heterogennya vegetasi yang ada.

Faktor yang sebenarnya cukup berpengaruh namun dalam penelitian ini diabaikan adalah tumbuhan bawah dan rumput yang berada diantara tegakan vegetasi. Hal ini sangat terlihat pada daerah bekas bencana awan panas yang terjadi pada tahun 1997 yang sebagian besar ditumbuhi oleh tumbuhan bawah dan rumput. Nilai indeks vegetasi pada daerah ini relatif sama dengan daerah dengan vegetasi jenis akasia yang kerapatan tegakannya sedang namun mempunyai tumbuhan bawah dan rumput yang cukup lebat diantara tegakan-tegakan akasia. Hal ini dapat mengakibatkan kesalahan dalam klasifikasi melalui citra indeks vegetasi.

Di daerah kajian yang masuk daerah administrasi Klaten status hutan tidak dipegang oleh Dinas Kehutanan namun dipegang oleh Perhutani. Hal ini menyebabkan adanya bagian dari hutan yang digunakan untuk budidaya tanaman penduduk seperti jenis jagung. Hal ini berpengaruh terhadap nilai indeks vegetasinya yang kemungkinan besar akan mengakibatkan kesalahan dalam klasifikasi. 
Pemanfaatan Transformasi Normalized Difference Vegetation Index (Ndvi) Citra Landsat TM untuk Zonasi Vegetasi di Lereng Merapi Bagian Selatan

\section{Tinjauan Terhadap Pengolahan Data}

Pengambilan sampel lapangan dilakukan secara random namun sistematik, posisi titik sampel ditentukan berdasarkan pengelompokkan nilai indeks vegetasi pada citra. Masing-masing pengelompokkan nilai tersebut minimal diambil 1 titik sampel. Diharapkan dengan metode seperti ini semua obyek kajian dapat terwakili. Topografi daerah yang bergunung dan sangat curam perlu juga mendapat perhatian dalam penentuan lokasi titik sampel. Dari masing-masing titik sampel diambil parameterparameter yang diprelukan dalam penelitian, seperti identifikasi jenis vegetasi, pengukuran kerapatan tegakan, dan penentuan umur vegetasi. Data mengenai kerapatan tegakan dan umur vegetasi mengacu pada data yang terdapat di kartu kendali petak RPH Kaliurang. Pengukuran langsung dilapangan dilakukan hanya bila dirasa terdapat perubahan yang signifikan, seperti akibat dari bencana awan panas yang terjadi pada tahun 1997 yang membakar vegetasi hutan di bagian barat. Identifikasi jenis pada satu kawasan hutan sebenarnya sangat beragam, namun dalam penelitian ini identifikasi dilakukan pada jenis dominan pada komunitas vegetasi.

Posisi titik-titik sampel di lapangan diplotkan pada posisi piksel yang sama pada citra indeks vegetasi untuk dianalisis kekuatan hubungan antara data lapangan dengan nilai kecerahan pada citra tersebut. Tiap-tiap titik sampel dijadikan dasar dalam mengklasifikasi citra indeks vegetasi menjadi peta jenis vegetasi, peta kerapatan tegakan, dan peta umur vegetasi. Seperti telah disebutkan di depan bahwa ekstraksi informasi pada citra indeks vegetasi efektif digunakan untuk daerah dengan liputan vegetasi yang homogen. Namun karena daerah penelitian mempunyai liputan vegetasi yang cukup heterogen sehingga identifikasi parameter adalah parameter dominan dalam suatu komunitas vegetasi yang heterogen. Sebenarnya informasi yang terkandung dalam citra indeks vegetasi merupakan nilai rata-rata dari campuran berbagai macam vegetasi yang kemungkinan dapat membuat kesalahan dalam proses analisis selanjutnya.

Hasil klasifikasi jenis vegetasi mempunyai keakuratan yang cukup tinggi, hanya terjadi kesalahan pada sampel bambu yang 1 piksel terklasifikasi sebagai lahan tak bervegetasi, sampel puspa terdapat 7 piksel yang terklasifikasi pinus, sampel akasia 1 piksel terklasifikasi lahan tak bervegetasi, dan sampel pinus terdapat 15 piksel yang terklasifikasi lahan tak bervegetasi dan 9 piksel terklasifikasi puspa. Secara umum tingkat ketelitian klasifikasi jenis vegetasi sebesar $93 \%$. Sedangkan untuk klasifikasi kerapatan tegakan dan umur vegetasi mempunyai tingkat ketelitian sebesar $71 \%$ dan $76 \%$.

Tabel 7. Uji ketelitian interpretasi jenis vegetasi

\begin{tabular}{|l|r|r|r|r|r|r|}
\hline \multirow{2}{*}{$\begin{array}{l}\text { Kelas di } \\
\text { Lapangan }\end{array}$} & \multicolumn{5}{|c|}{ Kelas Data Landsat } & \multirow{2}{*}{ Total } \\
\cline { 2 - 7 } & Tak Bervegetasi & Bambu & Puspa & Akasia & Pinus & \\
\hline Tak Bervegetasi & 231 & 1 & 0 & 1 & 15 & 248 \\
\hline Bambu & 0 & 17 & 0 & 0 & 0 & 17 \\
\hline Puspa & 0 & 0 & 13 & 0 & 9 & 22 \\
\hline Akasia & 0 & 0 & 0 & 23 & 0 & 23 \\
\hline Pinus & 0 & 0 & 7 & 0 & 149 & 156 \\
\hline Total & 231 & 18 & 20 & 24 & 173 & 466 \\
\hline
\end{tabular}


Tingkat ketelitian interpretasi jenis vegetasi

$\frac{231+17+13+23+149}{466} \times 100 \%=93 \%$

Tabel 8. Uji ketelitian interpretasi kerapatan tegakan

\begin{tabular}{|l|r|r|r|r|r|}
\hline \multirow{2}{*}{$\begin{array}{c}\text { Kelas di } \\
\text { Lapangan }\end{array}$} & \multicolumn{4}{|c|}{ Kelas Data Landsat } & \multirow{2}{*}{ Total } \\
\cline { 2 - 6 } & Tak Bervegetasi & Jarang & Sedang & Rapat & \\
\hline Tak Bervegetasi & 231 & 0 & 0 & 0 & 231 \\
\hline Jarang & 0 & 160 & 0 & 0 & 160 \\
\hline Sedang & 0 & 114 & 2 & 0 & 116 \\
\hline Rapat & 0 & 2 & 98 & 141 & 241 \\
\hline Total & 231 & 276 & 100 & 141 & 748 \\
\hline
\end{tabular}

Sumber : Hasil Analisis tahun 2004

Tingkat ketelitian interpretasi kerapatan tegakan

$\frac{231+160+2+141}{748} \times 100 \%=71 \%$

Tabel 9. Tabel Uji Ketelitian Interpretasi Umur Vegetasi

\begin{tabular}{|c|c|c|c|c|}
\hline \multirow{2}{*}{ Kelas di Lapangan } & \multicolumn{3}{|c|}{ Kelas Data Landsat } & \multirow{2}{*}{ Total } \\
\hline & $6-28$ th & $29-50$ th & $51-72$ th & \\
\hline $6-28$ th & 58 & 21 & d & 21 \\
\hline $29-50$ th & 0 & 48 & 13 & 61 \\
\hline $51-72$ th & 0 & 0 & 3 & 3 \\
\hline Total & 58 & 69 & 16 & 143 \\
\hline
\end{tabular}

Sumber : Hasil Analisis tahun 2004

Tingkat ketelitian interpretasi umur vegetasi

$\frac{58+48+3}{143} \times 100 \%=76 \%$

\section{Kesimpulan}

1. Jenis, kerapatan tegakan, dan umur vegetasi mempunyai pengaruh yang sangat nyata terhadap nilai transformasi indeks vegetasi (NDVI) data digital Landsat TM.

2. Jenis pinus mempunyai rata-rata nilai transformasi indeks vegetasi (NDVI) sebesar 0,592082, akasia sebesar 0,396662, bambu sebesar 0,476632, dan puspa sebesar 0,543649 .

3. Vegetasi dengan kerapatan jarang mempunyai rata-rata nilai transformasi indeks vegetasi (NDVI) sebesar 0,141146, kerapatan sedang sebesar 0,403262, dan kerapatan tinggi sebesar 0,593144.

4. Vegetasi dengan umur $6-28$ tahun mempunyai rata-rata nilai transformasi indeks vegetasi sebesar 0,424632, umur $29-50$ tahun sebesar 0,513008, dan umur $51-72$ sebesar 0,608477 . 
5. Kerapatan tegakan vegetasi mempunyai pengaruh yang kuat terhadap nilai indeks vegetasi (NDVI) data digital Landsat TM dengan nilai koefisien korelasi 0,802285, dan dari analisis regresi menghasilkan hubungan $Y=0,304018 X^{0,011658}$.

6. Umur vegetasi mempunyai pengaruh yang kuat terhadap nilai transformasi indeks vegetasi (NDVI) data digital Landsat TM dengan nilai koefisien korelasi 0,999932, dan dari analisis regresi menghasilkan hubungan $Y=0,471496 X^{0,009666}$.

7. Analisis digital data citra Landsat TM melalui penerapan transformasi indeks vegetasi (NDVI) dapat dengan baik mengidentifikasi vegetasi dengan tingkat ketelitian secara keseluruhan untuk interpretasi jenis vegetasi $93 \%$, kerapatan tegakan $71 \%$, dan umur vegetasi $76 \%$.

\section{Daftar Pustaka}

Danoedoro, P., 1996, Pengolahan Citra Digital Teori dan Aplikasinya Dalam Bidang Penginderaan Jauh, Modul Kuliah, Fakultas Geografi, Universitas Gadjah Mada, Yogyakarta.

Kriswantoro, J., 1997, Penggunaan Data Penginderaan Jauh untuk Estimasi Potensi Volume Kayu Hutan (Studi Kasus Pada Tegakan Jati, Mahoni, dan Sonokeling di Bagian Hutan Karangsono, KPH Telawa-Jawa Tengah), Skripsi S1, Fakultas Geografi, Universitas Gadjah Mada, Yogyakarta.

Kuchler, A. W., 1967, Vegetation Mapping, University of Kansas, The Ronald Press Company, New York.

Laksono, Y. A., 2002, Pemrosesan Informasi Spektral Data Digital Landsat Thematic Mapper untuk Estimasi Produksi Daun Kayu Putih Di Bagian Daerah Hutan Karangmojo Gunung Kidul, Tugas Akhir, Program Diploma, Fakultas Geografi, Universitas Gadjah Mada, Yogyakarta.

Sutanto, 1986, Penginderaan Jauh (Jilid I), Gadjah Mada University Press, Yogyakarta.

Sutanto, , Penginderaan Jauh (Jilid II), Gadjah Mada University Press, Yogyakarta. 